\title{
Isolation of Indigenous Hydrocarbon Transforming Bacteria from Oil Contaminated Soils in Libya: Selection for Use as Potential Inocula for Soil Bioremediation
}

\author{
Althalb Hakima ${ }^{1, *}$, Singleton $\operatorname{Ian}^{2}$ \\ ${ }^{1}$ Industrial and Production Chemistry Department, Libyan Petroleum Institute, Tripoli, Libya \\ ${ }^{2}$ School of Applied Sciences, Edinburgh Napier University, Edinburgh, United Kingdom \\ *Corresponding author: althalb798@yahoo.com
}

\begin{abstract}
The Libyan oil industry has left a significant legacy of contamination and methods are required to remediate oil-contaminated soils in the area. In this work hydrocarbon utilizing microorganisms were isolated and identified from contaminated soil samples obtained from an oil Refinery (Zawia, Libya). After initial screening of eleven isolates capable of growth on hexadecane, the five most promising hydrocarbon-utilizing bacteria were isolated and tested for biosurfactant production and emulsification activity. They were identified (using 16S rRNA sequence analysis) as Pseudomonas putida, Pseudomonas species, Betaproteobacterium, Actinomyces species, and Bacillus species. Among the five species tested, Pseudomonas putida showed superior performance in terms of growth on hydrocarbons $\left(1.0 \times 10^{10} \mathrm{CFU}(\mathrm{ml})\right)$, E24 emulsifying activity $(86 \%)$ and ability to transform hydrocarbons in pure culture. Interestingly, gas chromatographic analysis of crude oil treated with $P$. putida showed a decrease in heavy hydrocarbon fractions demonstrating a clear potential for this microbe to be used as a soil inoculant in bioremediation.
\end{abstract}

Keywords: Biosurfactant, Emulsifying Activity, hydrocarbon-utilizing bacteria, Pseudomonas putida, Betaproteo bacterium, Actinomyces species, Bacillus species

Cite This Article: Althalb Hakima, and Singleton Ian, "Isolation of Indigenous Hydrocarbon Transforming Bacteria from Oil Contaminated Soils in Libya: Selection for Use as Potential Inocula for Soil Bioremediation." International Journal of Environmental Bioremediation \& Biodegradation, vol. 5, no. 1 (2017): 8-17. doi: 10.12691/ijebb-5-1-2.

\section{Introduction}

Pollution with petroleum and its products is considered a major problem worldwide due to its impact on human health and the environment. Petroleum hydrocarbons are considered to be the most common group of persistent organic contaminants and are known to be toxic to many organisms (e.g. [16,40]). Moreover it has been shown that petroleum hydrocarbons cause significant losses in soil quality due to their toxicity towards biological processes catalyzed by soil microorganisms as in [35].

Reddy et al. [40] discussed a variety of biological processes which are affected by petroleum products due to their carcinogenicity, pointing out that the toxic compounds of petroleum hydrocarbons are accumulated in tissues, "causing genetic mutations and cell atrophy. The purpose of remediating contaminated sites is not to remove every last drop of contamination for the sake of it, but to protect human health and the environment and eventually to attain sustainable development as in [24]. During the last century hydrocarbon contamination has become a major environmental problem as a result of the manufacture, transportation, and distribution of petroleum products [9]. Since the activities of the oil associated industry in Libya have expanded, high levels of hydrocarbon contamination have been recorded at several sites. In particular the Libyan coast, where oil industries are located are affected by serious oil pollution and for the last $40-50$ years in the Mediterranean ecosystem, the levels of petroleum hydrocarbon have increased [1]. Soil and groundwater contamination was recorded in the western part of Libya caused by pipeline corrosion (Libyan Petroleum Institute reports). Additional studies have observed high levels of TPHs in the Gulf of Sirte in the North of Libya and 35000 $\mathrm{mg} / \mathrm{kg}$ of petroleum hydrocarbons were recorded in soil contaminated by crude oil and petroleum products in the area surrounding the Zawia refinery in the west of Libya $[2,15]$.

Despite the level of oil contaminated soil known to be present in Libyan soils relatively little work has been carried out on the potential bioremediation of these soils. These sandy soils may lack the appropriate hydrocarbon degraders and nutrients required for the removal of hydrocarbons by bioremediation. For example, McMillen [27] compared biodegradation rates between sandy soils and clay soils; and found that sandy soils have lower biodegradation potential than clay and loam soils. The reasons for the low biodegradation of sandy soils maybe due to low numbers of hydrocarbon degraders present, low water holding capacity, low total organic carbon 
content, and/or low surface area available for growth. To address some of these issues this work aimed to isolate hydrocarbon-transforming bacteria from oil contaminated sandy soil from Libya and to assess their potential to be used as inocula to assist the bioremediation of such soils.

\section{Materials and Methods}

\subsection{Physical and Chemical Characterization of the Soil and Contaminants}

\subsubsection{Collection of Samples}

The site used in this study was the Zawia Oil Refinery, where different fuels including naphtha, gasoline, kerosene, light vacuum gas oil (VGO), fuel oil, base lubricating oils, and asphalt are processed. Twelve hydrocarbon contaminated soil samples of approximately $1 \mathrm{~kg}(0-15 \mathrm{~cm}$ depth) were collected from around four oil storage tanks located at Zawia Oil Refinery, Libya, in June 2008. Soil samples were collected to reflect a range of hydrocarbon concentrations and to represent various potential sources of contamination. Samples were placed in plastic bags and cooled for transportation. After the soil samples were received at the LPI (Libyan Petroleum Institute) microbiological laboratory, the soil was air dried for 48 hours and all samples mixed to obtain one homogenous sample. One homogenous sample was used as any future potential large scale bioremediation would be carried out on such a mixed soil and so that a manageable number of laboratory manipulations could be carried out. Soils were sieved to $2 \mathrm{~mm}$ and subsamples of $500 \mathrm{~g}$ were set aside for soil analysis.

\subsubsection{Soil Analysis}

Soil texture: Particle size was determined using a Master Sizer 2000 (Malner International) at a chemical analysis laboratory, namely the Libyan Petroleum Institute (LPI). The petroleum products that contaminated the soil samples were extracted using a Soxhlet Extraction System (SES). Dichloromethane was used for the extraction.

\subsubsection{Soil pH}

Soil $\mathrm{pH}$ was determined using a $\mathrm{pH}$ meter (Jenway 3020) on soil suspensions in water in triplicates as described in [10]. Twenty five grams of soil was stirred continuously with $50 \mathrm{ml}$ of d-eionised water d.d. $\mathrm{H}_{2} \mathrm{O}$ for 15 minutes and allowed to equilibrate for another 15 minutes. The $\mathrm{pH}$ meter was immersed in the supernatant and was rotated gently before recording $\mathrm{pH}$.

\subsubsection{Moisture Content and Water Holding Capacity (WHC)}

Moisture content was determined by drying $10 \mathrm{~g}$ of the soil sample in an oven at $105^{\circ} \mathrm{C} .10 \mathrm{~g}$ of oven dried soil was placed on filter papers (Whatman No. 42) and fitted into Buchner funnels. De-ionised water was added slowly (at a rate of $1 \mathrm{~cm} \mathrm{hr}^{-1}$ ) until the water level was just above the soil surface, he soil was saturated and dripping into the flask below. The funnel was then removed and left to drain overnight until no further drainage occurred. The soil was left for 24 hours, rewetted to saturation and the whole apparatus was reweighed. The percentage of moisture content of the soil in triplicate was then determined. Water holding capacity $(100 \%)$ was then calculated.

\subsection{Isolation and Purification of Hydrocarbon Degrading Bacteria from Contaminated Soil (Using Hexadecane)}

Two grams of the homogenized hydrocarbon contaminated soil samples were added to $50 \mathrm{ml}$ of Enrichment Medium (EM) $\left(\mathrm{NH}_{4}\right)_{2} \mathrm{SO}_{4}$ (1.5); $\mathrm{NaH}_{2} \mathrm{PO}_{4} . \mathrm{H}_{2} \mathrm{O}(1.5) ; \mathrm{K}_{2} \mathrm{HPO}_{4}$ (4.65); $\mathrm{KCl}(0.1) ; \mathrm{MgSO}_{4} .7 \mathrm{H}_{2} \mathrm{O}(0.2)$; Yeast Extract (0.5); Peptone (0.5); Casamino Acid (0.5); Trace Elements (2.0), $(\mathrm{pH}=7.1)$, and varying hydrocarbon (hexadecane) concentrations $0.1 \%, 1.0 \%$, and $5.0 \%(\mathrm{v} / \mathrm{v})$ were added. Cultures were grown in $250 \mathrm{ml}$ Erlenmeyer flasks and incubated with shaking at $150 \mathrm{rpm}$ for $7 \mathrm{~d}$ at $37^{\circ} \mathrm{C}$, and $30^{\circ} \mathrm{C}$ for the purpose of isolating hydrocarbon utilizing bacteria from contaminated soil samples, as well as to evaluate their optimum growth temperature. Eleven bacteria were isolated and purified using two types of solid growth media. Solid mineral salt media was used and nhexadecane was added on a disc of sterilized filter paper and placed in the lid on the plate as the carbon and energy source. Solid Bushnell Hass medium was also inoculated with $1 \mathrm{ml}$ of the same culture with a layer of filter paper supplemented, with either $1 \mathrm{ml}$ of n-hexadecane or diesel oil, onto the agar in order to develop the embedded colonies [17] following a similar method to that of Supaphol et al. [47]. Isolated bacterial species were evaluated using different temperature levels and hydrocarbon concentration to determine their ability to grow on hydrocarbons (using hexadecane as a sole carbon source) and their optimum growth temperatures. In addition, bacterial isolates were grown on phenol red dextrose (PRD) medium which is designed for general aerobic and facultative anaerobic bacteria for seven days at $30^{\circ} \mathrm{C}$, and then isolates were gram stained. After this five bacterial species showing the best growth on hexadecane were selected, and their ability to grow on crude or diesel oil as a sole carbon source was determined (see below).

\subsubsection{Ability of Pure Cultures of Hydrocarbon Degrading Bacteria to Grow on Crude Oil or Diesel Oil as Sole Carbon and Energy Sources}

Five pure cultures of hydrocarbon degrading bacteria (isolated as above - section 2.2) were grown in enrichment medium containing $0.1 \%$ (v/v) of $\mathrm{n}$ hexadecane. Cultures were grown in $250 \mathrm{ml}$ Erlenmeyer flasks and incubated with shaking at $150 \mathrm{rpm}$ for $7 \mathrm{~d}$ at $30^{\circ} \mathrm{C}$. Then each of the cultures grown were transferred to two sets of mineral medium containing (g/L) $\mathrm{NaNO}_{3}$ (4); $\mathrm{Na}_{2} \mathrm{HPO}_{4}(0.5) ; \mathrm{KH}_{2} \mathrm{PO}_{4}(1.5) ; \mathrm{KCl}(0.1) ; \mathrm{MgSO}_{4} .7 \mathrm{H} 2 \mathrm{O}$ (0.2); $\mathrm{CaCl}_{2}$ (0.01); $\mathrm{FeSO}_{4} \cdot 7 \mathrm{H}_{2} \mathrm{O},(0.0011)$; and yeast extract (0.1).The medium was supplemented with $1 \mathrm{~mL}$ of the trace elements solution (Gerhardt, 1981; Plaza, 2008) $(\mathrm{mg} / \mathrm{L}): \quad \mathrm{ZnSO}_{4} .7 \mathrm{H}_{2} \mathrm{O} \quad(50) ; \quad \mathrm{MnCl}_{2} \cdot 4 \mathrm{H}_{2} \mathrm{O} \quad$ (400); $\mathrm{CoCl}_{2} \cdot 6 \mathrm{H}_{2} \mathrm{O}$ (1); $\mathrm{CuSO}_{4} .5 \mathrm{H}_{2} \mathrm{O}(0.4) ; \mathrm{H}_{3} \mathrm{BO}_{2}$ (2); and $\mathrm{Na}_{2} \mathrm{MoO}_{4} \cdot 2 \mathrm{H}_{2} \mathrm{O}$ (500). One set contained $1.0 \%$ (v/v) of diesel oil and the other set contained $1.0 \%(\mathrm{v} / \mathrm{v})$ of crude oil. All cultures were incubated at $30^{\circ} \mathrm{C}$ for 15 days. The five bacterial isolates with the ability to grow on target hydrocarbons were assessed further using growth rate, 
emulsification index, and biosurfactant production as assessment parameters. The purpose of this was to reduce the number of isolates studied to a manageable level i.e. select the bacteria that grew best on diesel oil and crude oil as a sole carbon source.

\subsubsection{Growth Condition Optimization}

Growth of the five isolates was monitored by measuring the optical density (OD) at a wavelength of using a spectrophotometer (Jenway Series 6105 UV-Vis) at $540 \mathrm{~nm}$. Doubling time (Td) and the maximum specific growth rate $\left(\mu_{\max }\right)$ of the five isolates as a pure culture were calculated.

\subsubsection{Emulsification Activity Measurement}

The hydrocarbon degraders isolated were grown on emulsified crude oil and n-hexadecane. The emulsification activity (E24) was assessed using the Kerosene test as in [11]. Test oil substrates $(2 \mathrm{ml})$ of kerosene and diesel were used and added to an equal volume of the overnight culture broth in a test tube, and then mixed for 2 minutes (vortexed). The emulsion stability was determined after 24 hours by dividing the measured height of the emulsion layer by the mixture's total height, multiplied by 100 . The equation used to determine the emulsion index E24 (\%) is as follows: E24 $(\%)=$ the height of the emulsion layer / the height of the total solution $\times 100 \%$ (e.g. $[4,20]$ ). The bacteria with the best abilities to produce biosurfactant and grow on oils were then selected and studied further for their ability to degrade hydrocarbons.

\subsubsection{Assessment of Hydrocarbon Transformation Ability}

In this section, two pure isolates (LPI HKB and LPI HKW) with maximum specific growth rates and the best emulsifying activity on crude oil as a carbon source were selected for further investigation so as to determine their ability to transform HCs. Their growth rates under different conditions (hydrocarbon concentrations $0.1 \%$ and $1.0 \%(\mathrm{v} / \mathrm{v})$, as well as temperatures $37^{\circ} \mathrm{C}$ and $30^{\circ} \mathrm{C}$ were assessed. The inocula of two species were prepared by growth on Nutrient Broth (OXOID) at $30^{\circ} \mathrm{C}$ for 18 hours in an orbital shaker at $150 \mathrm{rpm}$. The culture broth was centrifuged (8.000rpm for $10 \mathrm{~min}$ ), and the supernatant medium discharged. The cell pellets obtained were rinsed in sterile saline. The cell mass was collected and suspended in $20 \mathrm{ml}$ of mineral salt medium (used as inoculum). The suspensions containing $10^{4}-10^{5}$ cells $\mathrm{mL}^{-1}$ of pure cultures were used as inocula in a large chemostat culture vessel for the biodegradation experiment (see below - section 2.3).

\subsection{Biodegradation of Crude Oil and Diesel Oil Experiments}

To assess the ability of the isolated strains LPI HKB and LPI HKW to grow in crude oil and diesel oil as sole carbon sources and degrade long-chain crude oil and petroleum hydrocarbons, cells of $10-\mathrm{ml}$ from two overnight pure cultures $\left(10^{4}-10^{5}\right.$ cells $\left./ \mathrm{ml}\right)$ were used to inoculate $1800 \mathrm{ml}$ of mineral salt medium (MSM, supplemented with $1.0 \%(\mathrm{v} / \mathrm{v})$ of commercial diesel fuel and crude oil in a large chemostat culture vessel. The system was set up by calibrating the $\mathrm{pH}$ between 7.0 - 7.3. The temperature was set at $30^{\circ} \mathrm{C}$ and the stirring rate was set at an upper limit of 250rpm. Bacterial growth was estimated by two parameters: colony forming units (CFU/ml -see section 2.3.1) and optical density of the cultures at 540nm using a Jenway Series 6105 UVVisspectrophotometer. Residual TPH values were assessed after 21 days of incubation on diesel oil, and crude oil by gas chromatography (section 2.3.3). Sterile controls were also set up for comparison purposes.

\subsubsection{Microbiological Studies: Determination of Microbial Population by Plate-Count Method}

The estimation of total bacterial number in liquid culture samples were evaluated by spread plate methods from chemostat culture samples taken on days 0,7 and 21 . Culture $(1 \mathrm{~mL})$ was suspended in $9 \mathrm{ml}$ of $1 / 4$ strength ringers solution and shaken for $10 \mathrm{~min}$ (with a vortex mixer) to achieve a homogenized suspension. Following suspension, the supernatant containing bacterial cells were serially diluted with Ringers solution. A series of dilutions was then carried out, up to $10^{-7}$ at the start of the experiment. A sample $(0.1 \mathrm{ml})$ of the appropriate dilution was then inoculated onto sterile, 20-ml Petri dishes containing Nutrient Agar (DIFCO). Colonies on the plates were counted after incubation for 7 days at $30^{\circ} \mathrm{C}$. The number of colony forming units per milliliter culture $(\mathrm{CFU} / \mathrm{mL})$ was calculated.

\subsubsection{Crude Oil and Diesel Oil Extraction}

The crude oil was extracted from MSM after 21d of incubation using liquid-liquid extraction techniques by a mixture of $n$-hexane and dichloromethane (1:1). After extraction the solvent was evaporated. Crude oil extracts were subject to distillation to obtain the boiling distribution of the petroleum components. Diesel oil was extracted using the same organic solvent system $n$-hexane and dichloromethane. The total remaining content of the culture vessel $(1500 \mathrm{~mL}$, as some of the volume was taking for chemical and microbiological analyses) was transferred to a liquid-liquid extractor and $250 \mathrm{~mL}$ of solvent mixture added. The extracted solution was then dried through solvent washed anhydrous sodium sulfate using Whatman filter paper number 50. Extracted crude oil and diesel oil samples were analysed using gas chromatography.

\subsubsection{Gas Chromatograph Analysis}

Analyses of $n$-alkanes and total petroleum hydrocarbons were performed at the beginning and end ( 21 days) of the chemostat incubation using a Chrompack Model 439 capillary gas chromatograph flame ionization detector (FID).The gas chromatographic analyses were conducted with a $300^{\circ} \mathrm{C}$ detector, $300^{\circ} \mathrm{C}$ injector, split ratio on $100: 1$ and samples of $0.1 \mu \mathrm{l}$ injections. A column temperature of $40^{\circ} \mathrm{C}$ was held for $2 \mathrm{~min}$ and then ramped at a rate of $5^{\circ} \mathrm{C} / \mathrm{min}$ to a final temperature of $300^{\circ} \mathrm{C}$ and held for 30 min. Degradation in the liquid chemostat culture was estimated as the difference between the initial and final concentrations of total hydrocarbons [38]. 


\subsection{Identification of Isolates by $16 \mathrm{~S}$ rRNA Analysis}

DNA was extracted from the bacterial colonies according to the protocol described by Sigma's GenElute Bacterial Genomic Kit. Cell harvest; $1.5 \mathrm{~mL}$ of an overnight bacterial broth (NB) culture was centrifuged for 2 minutes at $12,000-16,000 \times \mathrm{g}$, and the supernatant discarded. The cell pellet was re-suspended thoroughly in $200 \mu 1$ of Lysozyme solution prepared previously and incubated for 30 minutes at $37^{\circ} \mathrm{C}$. Twenty $\mu \mathrm{l}$ of the proteinase $\mathrm{K}$ solution was added to the sample. This was followed by $200 \mu \mathrm{l}$ of Lysis Solution C, and the solution mixed thoroughly by vortexing at 15 seconds. The sample was then incubated at $55^{\circ} \mathrm{C}$ for 10 minutes.

Five hundred $\mu \mathrm{l}$ of Column Preparation Solution were added to each pre-assembled GenEluteMinprep binding column seated in a $2 \mathrm{~mL}$ collection tube. Centrifugation at $12,000 \times \mathrm{g}$ for 1 minute was carried out and then the eluate was discarded. Two hundred $\mu 1$ of the ethanol (95-100\%) was added to the lysate and mixed thoroughly by vortexing to 5-10 seconds to obtain a homogeneous mixture. The contents of the tube were transferred to the binding column, and then centrifuged at $6500 \times \mathrm{g}$ for 1 minute. The collection tube containing the eluate was discarded and then the column was placed in a new $2 \mathrm{~mL}$ collection tube. In the first wash, $500 \mu \mathrm{l}$ of wash solution was added to the column and centrifuged for 1 minute at $6500 \times \mathrm{g}$, discarding the collection tube containing the eluate and placing the column in a new $2 \mathrm{~mL}$ collection tube. Another $500 \mu \mathrm{l}$ of wash solution was added to the column and centrifuged for 3 minutes at maximum speed $(12,000-16,000 \times \mathrm{g})$ to dry the column. The column had to be free of ethanol before eluting DNA, so the column was centrifuged at maximum speed for an extra 1 minute. The collection tube containing the eluate was discarded and then the column was placed in a new $2 \mathrm{~mL}$ collection tube. Two hundred $\mu 1$ of elution solution was pipetted onto the center of the column and centrifuged at $6500 \times \mathrm{g}$ for 1 minute to elute the DNA.

\subsubsection{Checking DNA Integrity by Electrophoresis}

Four $\mu 1$ of DNA extract with $2 \mu 1$ loading dye was combined and then loaded onto $1 \%(\mathrm{w} / \mathrm{v})$ agarose gel with ethidium bromide, $0.5 \mathrm{x}$ TBE loading buffer $(0.5 \mu \mathrm{l} / \mathrm{ml})$. Two $\mu 1$ 100bp ladder markers were loaded and the gel was run at $100 \mathrm{~V}$ for 30 minutes. Extracted DNA was diluted with PCR grade water to $1: 10,1: 25$, and 1:50 for PCR reaction.

\subsubsection{PCR Amplification of $16 S$ rRNA Gene}

PCR Conditions and Optimization: Genomic DNA from hydrocarbon degraders were amplified by polymerase chain reaction (PCR) using the specific bacterial primers $27 \mathrm{f}$ and $1525 \mathrm{r}$ (see Table 1). These are universal primers that bind at the conserved 5 and $3{ }^{`}$ ends of $16 \mathrm{~S}$ rRNA of the eubacteria. PCR amplification was performed using $50 \mu \mathrm{l}$ of PCR reaction mixture containing $5.0 \mu \mathrm{l}$ of $10 \mathrm{X} \mathrm{NH}_{4}$ Reaction buffer was added to $0.8 \mu \mathrm{l}$ dNTP (Bioline), mix (12.5 mM) each $1.0 \mu$ l Forward primer $27 \mathrm{f}(20 \mu \mathrm{M}), 1.0 \mu \mathrm{l}$ Reverse primer 1525 r $(20$ $\mu \mathrm{M}$ ), (Table 1) $3.0 \mu \mathrm{l} \mathrm{MgCl}_{2}, 38.0 \mu \mathrm{l}$ Sterile Milli - Q water, $0.5 \mu \mathrm{l}$ Taq polymerase (Bioline). Forty-nine $\mu 1$ of
PCR reaction mixture solution was transferred to each of the seven microfuge tubes. The first tube contained $49 \mu 1$ of solution with $1 \mu 1$ of distilled water, which formed the negative (-ve) control; the second tube contained $49 \mu 1$ with $1 \mu \mathrm{l}$ of genomic DNA (E. coli), which formed the positive (+ve) control; and five tubes contained $49 \mu 1+1 \mu \mathrm{l}$ of template DNA. The preparation was mixed and centrifuged for 5 seconds. All reagents used were from Bioline, London, UK. PCR was performed with a Biometra Thermal Cycler. The programme consisted of an initial step of 5 minutes at $95^{\circ} \mathrm{C}$, followed by 30 cycles, including a denaturing step at $95^{\circ} \mathrm{C}$ for 30 seconds, an annealing step at $55^{\circ} \mathrm{C}$ for 30 seconds, and an elongation step at $72^{\circ} \mathrm{C}$ for 1 minute. The last cycle was followed by a final extension at $72^{\circ} \mathrm{C}$ for 10 minutes. In order check the sizes of the PCR products, $4 \mu$ l of the PCR reactions were analyzed by $1.0 \%$ agarose gel electrophoresis in TAE (Tris acetic acid EDTA buffer, 1\% w/v; 30 minutes at $100 \mathrm{~V}, 0.5 \times \mathrm{TBE})$, stained with ethidium bromide, and visualized under UV light using image analysis software (Bio-Rad Gel Doc, Flour-S multi imager) as in [49]. The size of the amplified fragments was estimated by comparing with a $100 \mathrm{bp}$ molecular size marker.

\subsubsection{Sequencing of PCR Products}

The PCR products were cleaned up using ExoSAP-IT PCR clean-up kit, the protocol consists of a single pipetting step (enzyme mixture addition), a 15 -min incubation at $37^{\circ} \mathrm{C}$ followed by a further $15-\mathrm{min}$ incubation at $80^{\circ} \mathrm{C}$ for enzyme inactivation, then the PCR for products were sequenced by Geneius Laboratories Ltd (www.geneiuslabs.co.uk)) using Sanger sequencing based on a big dye terminator using an ABI 3730xl DNA sequencer. Sequences were viewed using MEGA software version 4.0. A contiguous sequence using forward and reverse sequences was made and the contiguous sequences were submitted to BLAST (https://www.ncbi.nlm.nih.gov/blast) for comparison with known data bases.

\subsubsection{Statistical Analysis}

Analysis of variance was used to compare data between soils in all treatments. All statistical analyses were performed using SPSS version 14 STATISTICA for Windows release 5.1 , in order determine whether or not the plate counts and biodegradation process resulted in statistically significant changes in $\mathrm{PH}$ transformation and microbiological parameters at a confidence level of $95 \%$ or P>0.05. Results were analysed by one way ANOVA followed by the Least Significant Difference (post hoc) test to determine individual differences between samples.

\section{Results}

\subsection{Soil Chemical and Physical Analysis - the Zawia Refinery}

The characteristics of the combined contaminated soil sample taken are presented in Table 2. A range of physical and chemical analyses carried out showed that soil texture was sandy and nutrient levels were low. Soil $\mathrm{pH}$ was neutral to slightly alkaline. Total petroleum hydrocarbon (TPH) content was $26532 \mathrm{mg}$ per $\mathrm{kg}, 0.0694$ ppm nitrogen, 
$9.6 \mathrm{ppm}$ phosphorus, and $3.17 \%$ moisture, grain size distribution (sand $76.8 \%$, silt $15.3 \%$ clay $7.9 \%$ ).

\subsection{Isolation and Study of Hydrocarbon- Degrading Bacteria Overview}

Firstly soil samples were added to enrichment medium (section 2.2) containing hexadecane as a sole $\mathrm{C}$ source and bacteria growing were plated out onto solid agar media containing either $n$-hexadecane or diesel as sole carbon sources. In order to reduce the number of isolates to a manageable level they were cultured at different temperatures and substrate (hexadecane) concentrations and the bacteria that grew best ( 5 cultures at this stage) selected for identification (by morphological and molecular methods) and further assessment i.e., ability to grow on crude or diesel oil as a carbon source and emulsification ability. The two best performing bacteria were then selected and assessed for their ability to grow on and transform (or degrade) crude oil and diesel. The main aim of this work was to isolate bacteria capable of transforming crude oil and diesel oil, and assess their suitability as potential microbial soil inoculants for bioremediation. To make the results more accessible only data relating to the selected isolates is presented below.

\subsubsection{Evaluation of Bacterial Isolates Capable of Growing on Hexadecane}

Altogether eleven bacterial isolates were isolated from the enrichment procedure (section 2.2.1). Selection of the most promising isolates was achieved by assessing their growth (spectrophotometry) on hexadecane in liquid culture (results not shown for purposes of clarity). The 5 bacteria showing the best growth (and labeled as LPI HKB, HKS, HKY, HKW and HKP) were identified. The isolates were gram-stained and examined under a microscope: see below for morphological descriptions and images (Figure 1). Isolate LPI HKW is gram-positive rod shaped bacterium and forms endospores. Cells appear as individuals and in chains; Isolate LPI HKY is a rodshaped gram-positive strain. The cells were filamentous similar in morphology to Actinomyces species and formed spores external to the cell, Isolate LPI HKS is a long rod shaped gram positive bacteria and appeared in aggregates, Isolate LPI HKB is a gram-positive rod shaped cell, Isolate LPI HKP forms large colonies that have regular edges and are cells are gram-negative, All bacterial strains were aerobes; except for LPI HKS, which was a facultative anaerobe. Microscopy and photomicroscopy: DIAPHOT 300/DIAPHOT200 epifluorescence microscope was used for observation the size and morphology of the bacterial colonies. A Lucia $\mathrm{G} / \mathrm{F}$ system with an image resolution of $97 \times 716$ pixels was attached to the microscope for photomicroscopy with $100 \times$ magnification objective; one pixel typically corresponds to 0.05-0.1 um. The 5 bacterial isolates were then identified using molecular techniques.

\subsubsection{Molecular-Based Identification of Bacterial Isolates}

The 5 bacterial isolates were characterized to genus level based on the complete sequence of the $16 \mathrm{~S}$ ribosomal RNA gene. The $16 \mathrm{~S}$ rRNA products were purified and sequenced (Section 2.4.3), the sequences of $16 \mathrm{~S}$ rRNA were submitted to BLAST under accession numbers FM211694.1, EF599311.1, AF282889.1, FM211694.1, and AF526907 respectively and the bacteria identified as in Table 3 (below). It was not possible to obtain full identification to species level of all the bacterial isolates.

\subsection{Effect of Temperature and Crude Oil Concentrations on Growth of the 5 Bacterial Isolates}

Pure cultures of the 5 selected bacteria were supplemented with different concentrations of crude oil - $0.1,1.0$, and $5.0 \%(\mathrm{v} / \mathrm{v})$ and incubated for 21 days. Growth of the isolated bacterial strains on different concentrations of crude oil was evaluated by measuring culture absorbance at 540nm using a spectrophotometer. Two sets of incubation temperature, $30^{\circ} \mathrm{C}$ and $37^{\circ} \mathrm{C}$, were used and all isolates showed better growth at $30^{\circ} \mathrm{C}$ and $1 \%$ hydrocarbon concentration in the batch culture test system (see Table 4). Results obtained at $37^{\circ} \mathrm{C}$ are not shown for clarity). The optimum growth rates of the different isolates on $1.0 \%(\mathrm{v} / \mathrm{v})$ of crude oil were calculated and showed that the Bacillus species and Pseudomonas putida grew quicker than other isolates on hydrocarbons of $1.0 \%(\mathrm{v} / \mathrm{v})$ at $30^{\circ} \mathrm{C}$. The maximum specific growth rates ( $\mu$ max) for the Pseudomonas species were $0.301 \mathrm{~h}^{-1}(P$. putida) and $0.436 \mathrm{~h}^{-1}$, for Bacillus species and $0.358 \mathrm{~h}^{-11}$ for the Nocardiacyria cigeorgici (Table 4). Overall, Pseudomonas putida and the Bacillus species gave the highest growth rate of the 5 isolates.

Table 1. Target Sites, Sequences and Specificity of Primers Targeting Small Subunit Ribosomal RNA Used for PCR Analysis [28]

\begin{tabular}{cccc}
\hline Primer & Target Site & Sequence (5'to3') & Specificity \\
\hline f27 & $137-156$ & AGAGTTTGATCCTGGCTCAG & Bacteria \\
r1525 & $1640-1658$ & AAGGAGGTGATCCAGCC & Bacteria \\
\hline
\end{tabular}

Table 2. General Physical and Chemical Properties of Contaminated Soil Samples Taken From the Oil Refinery Site. 12 Soil Samples Were Taken and Mixed to Homogeneity. The Bellow Results Reflect Values Obtained From the Homogenized Sample

\begin{tabular}{lc}
\hline \multicolumn{2}{c}{ Contaminated Soil Property } \\
\hline Sampling location & The Oil Refinery \\
Texture & Sand \\
$\mathrm{pH}$ & 7.64 \\
Water holding capacity (\%) & 3.17 \\
Moisture $(\%) @ 105^{\circ} \mathrm{C}$ & 3.51 \\
AvailableC(ppm) & $6.79 \%$ \\
Available N (ppm) & \\
NH ${ }_{4} \mathrm{~N}$ & $0.0694 \mathrm{ppm}$ \\
Available P (ppm) & $9.6 \mathrm{ppm}$ \\
Available K (ppm) & $32.4 \mathrm{ppm}$ \\
Total Petroleum Hydrocarbon $\mathrm{mg} / \mathrm{kg}$ & $26532 \mathrm{mg} / \mathrm{kg}^{-17}$ \\
CFU & $3.7 \times 10^{7} \mathrm{CFU} \mathrm{g}{ }^{-1}$ \\
\hline
\end{tabular}


Table 3. Identification of Selected Hydrocarbon-Degrading Bacterial Isolates by $16 \mathrm{~S}$ rDNA Gene Sequence

\begin{tabular}{cccc}
\hline \multirow{2}{*}{ Isolates } & \multicolumn{3}{c}{ 16S rDNA sequence comparison } \\
& Species as close relatives & Accession no. & Similarity (\%) \\
\hline LPI HKB & Pseudomonas putida & FM211694.1 & 100.0 \\
LPI HKS & Beta proteobacterium & EF599311.1 & 97.0 \\
LPI HKY & Nocardiacyriacigeorgici & AF282889.1 & 99.1 \\
LPI HKP & Pseudomona ssp. & FM211694.1 & 100.0 \\
LPI HKW & Bacillussp. & AF526907 & 99.1 \\
\hline
\end{tabular}

\subsubsection{Emulsification Activity Measurement}

The E24 (emulsification index) was measured at different stages of growth of the 5 bacterial isolates. Both of the Pseudomonas species and the Bacillus species showed a maximum E24 value after 48 hours of incubation (E24= 86\% for P. putida, $61 \%$ for Pseudomonas species and $66 \%$ for the Bacillus isolate), Table 5 shows the emulsification activity (E24) of all five isolates on kerosene. The emulsifying activity of all isolated species was highest during the stationary phase. Given that Pseudomonas putida and the Bacillus species performed better than all the other isolates (based on growth on oil and emulsification ability) these 2 isolates were used in all subsequent studies.

\subsubsection{Crude Oil Removal from Liquid Culture by Pseudomonas putida and Bacillus species}

The residual oil content was determined using soxhlet extraction of the culture by the procedure described in section 2.3.2. Reductions in TPH concentrations during growth on crude oil by both isolates are presented in Table 6 . During the log phase, crude oil-containing medium became emulsified. This indicates production of emulsifying agent by Pseudomonas putida and Bacillus species. Microbial growth resulted in a significant reduction $(\mathrm{p}<0.05)$ in light hydrocarbon fractions (C9-C14). Degradation of intermediate (C15- C20) crude oil was above 70\% after incubation of 21 days for Bacillus species, while it was $49 \%$ with Pseudomonas putida.

\subsubsection{Transformation of Diesel Oil by $P$. putida and Bacillus species}

Changes of TPH concentration during diesel oil degradation by both isolates (Pseudomonas putida and Bacillus species) are presented in Figure 2. Gas chromatographic analysis of diesel oil $1.0 \%(\mathrm{v} / \mathrm{v})$ treated with Pseudomonas putida and Bacillus species indicated that the TPH removal of diesel oil (1.0\% w/v) by Pseudomonas putida was higher than the biodegradation obtained by Bacillus species. The control samples, which had no bacteria added, showed losses of the total petroleum hydrocarbon to a certain extent but these losses were mainly in the shorter fraction and were significantly $(\mathrm{p}<0.05)$ less than observed in the bacterial treated cultures. During the experiment it was also observed that the transformation of different molecular weight compounds varied between the two bacteria. The addition of Pseudomonas putida species enhanced degradation of middle and long chain compounds compared with the control that was not supplemented with any microbial species, whereas Bacillus species resulted in significantly $(\mathrm{p}<0.05)$ greater degradation of middle-chain compounds than the control. Overall Pseudomonas putida was more effective in transforming the diesel oil than crude oil, while Bacillus species was more promising to grow and transform the crude oil. However transformation of the hydrocarbon compounds was higher with diesel oil compared to crude oil.

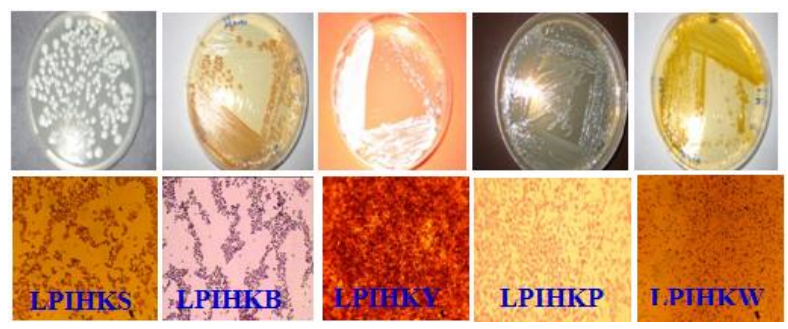

Figure 1. Colony Morphology and Gram Stain of The 5 Bacterial Isolates (labelled as LPI HKB, HKS, HKY, HKW and HKP) x 100 Magnification Was Used

Table 4. Optimum Growth rate of 5 Isolated Bacterial Strains on $0.1 \%, 1.0 \%$ and $5.0 \%$ Concentrations of Crude Oil at $30{ }^{\circ} \mathrm{C}$

\begin{tabular}{|c|c|c|c|c|c|}
\hline \multirow{2}{*}{ PH Conc. by vol } & \multicolumn{4}{|c|}{ Optimum Growth Rate $\mu$ hr 1 of isolates } \\
\cline { 2 - 5 } & Bacillus species & P. species & Nocardiacyri-acigeorgici & Beta proteobacterium & P. putida \\
\hline 0.1 & 0.134 & 0.0587 & 0.066 & 0.0445 \\
\hline 1.0 & 0.358 & 0.301 & 0.171 & 0.078 \\
\hline 5.0 & 0.158 & 0.176 & 0.067 & 0.436 & 0.044 \\
\hline
\end{tabular}

Table 5. Emulsification Activity on Kerosene of Five Hydrocarbon Degraders Isolates

\begin{tabular}{lc}
\hline \multicolumn{1}{c}{ Strains } & $\mathrm{E}_{24} \%$ \\
\hline Pseudomonas putida & 86 \\
Beta proteobacterium & 32 \\
Nocardiacyriacigeorgici & 53 \\
Pseudomonas species & 61 \\
Bacillus species & 66 \\
\hline
\end{tabular}

Table 6. Illustrates the removal of short/long chain alkanes (from C9 to $\mathrm{C14}$, and C15- C20) during crude oil degradation

\begin{tabular}{|l|c|c|}
\hline \multirow{2}{*}{ Fraction } & \multicolumn{2}{|c|}{ TPH Removal from crude oil } \\
& Bacillus species & Pseudomonas putida \\
\hline Light ( C9 - C14) & $73 \%$ & $63 \%$ \\
\hline Intermediate (C15- C20) & $73 \%$ & $49 \%$ \\
\hline Heavy (C21 - C26) & $42 \%$ & $37 \%$ \\
\hline
\end{tabular}

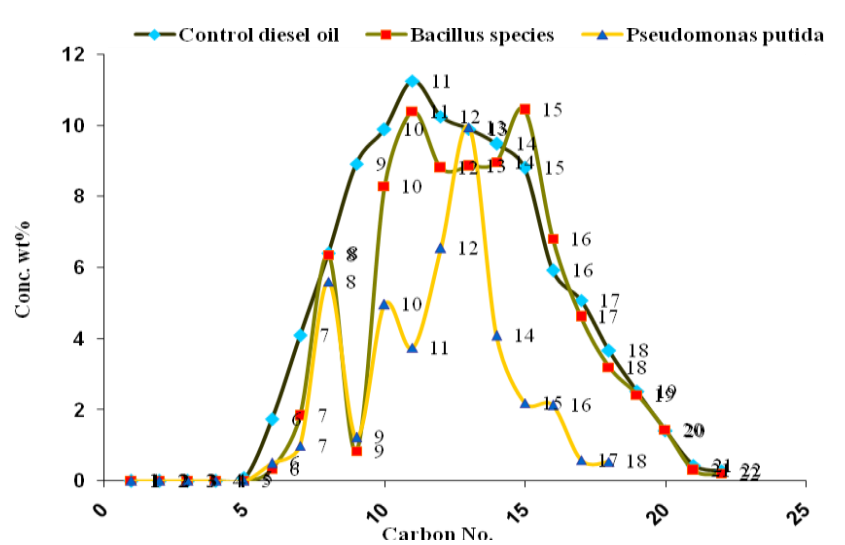

Figure 2. Transformation of Different Molecular Weight Compounds in Diesel Oil by P. putida and Bacillus species 


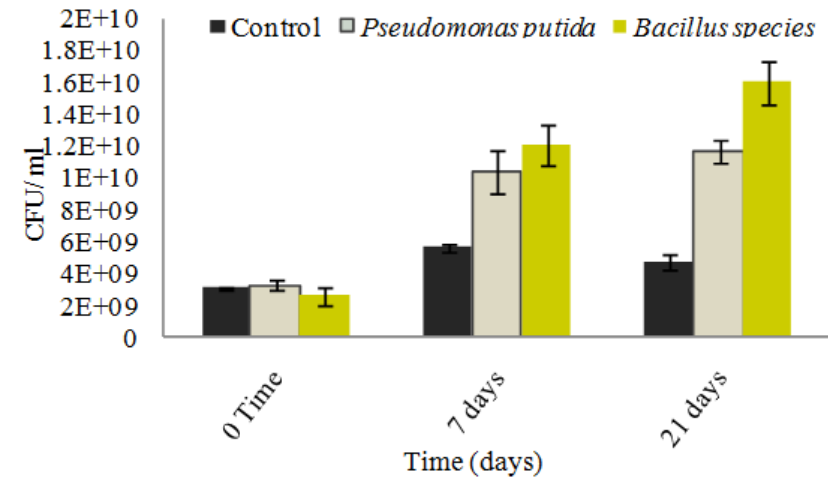

Figure 3. Changes in Hydrocarbon Degraders Counts (CFU/ml) on Crude Oil at the Initial and Final Time of Treatment

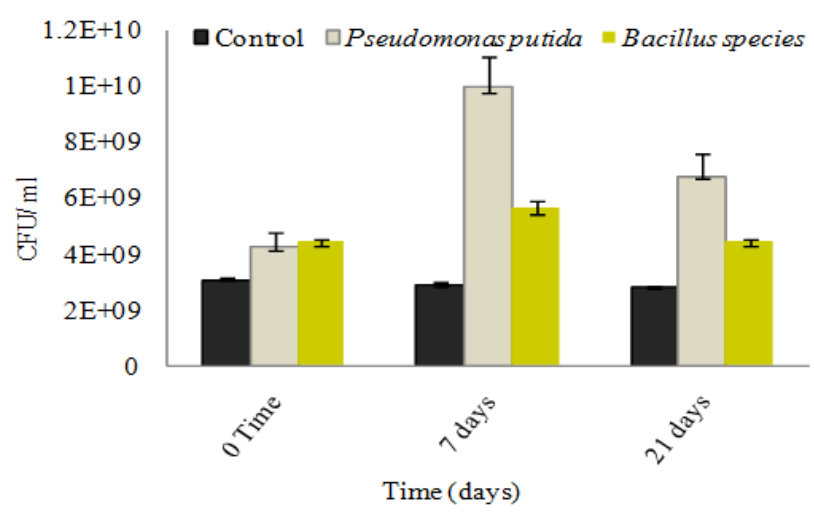

Figure 4. Changes in Hydrocarbon Degraders Counts (CFU /ml) on Diesel Oil at the Initial and Final Time of Treatment

\subsubsection{Change in Microbial Populations during Biodegradation of Oil (Diesel and Crude Oil)}

Results obtained from incubated cultures on different hydrocarbon sources are reported in Figure 3 and Figure 4. Growth with diesel oil started from day 3, while growth with crude oil started from day 7 . The incubated culture on diesel oil showed that bacterial counts increased during the experiment. Also, the addition of diesel oil was favorable for Pseudomonas species, whose counts reached a maximum of $1.0 \times 10^{10} \mathrm{CFU}(\mathrm{ml})$ by the middle of the biodegradation experiment. Bacillus species counts were generally higher in culture with crude oil than diesel oil. The initial count of Bacillus species in the incubated culture was found to be $2.5 \times 10^{9}$ colony-forming units CFU (ml). The number thus increased about 10-fold after 7 days of preparation of the culture (Figure 3).

\section{Discussion}

\subsection{Soil Properties}

It was very important to analyze the suitability of the site for a bioremediation operation, and determine the levels of contaminants, nutrients, soil type, and the presence of biodegrading microorganisms. Soil samples used in this study were sandy soils, which are low in nutrient levels, and this could limit the metabolism of the existing microorganisms capable of degrading hydrocarbons in the soil. For example, soils considered being high in $\mathrm{N}$ and $\mathrm{P}$ contain $9.80 \mathrm{mg} \mathrm{P}$ and $300.00 \mathrm{mg}$ total $\mathrm{N}$ respectively per $\mathrm{kg}$ as in [14], while the soils in this study only contained $0.0694 \mathrm{mg} \mathrm{N}$ and $9.6 \mathrm{mg} \mathrm{P}$ per $\mathrm{kg}$. The importance of nutrients to microbial processes has long been known. Nitrogen $(\mathrm{N})$ is required in amino acids, and phosphorus $(\mathrm{P})$ is involved in energy transport as adenosine triphosphate. Both $\mathrm{N}$ and $\mathrm{P}$ are significant factors in supporting microbial growth and frequently added to soils to enhance bioremediation [12], [30] and given the low $\mathrm{N}$ and $\mathrm{P}$ status of the soils in this study (coupled with the very high carbon content due to pollution) this means that these nutrients will be required to promote bioremediation of the soils. The level of hydrocarbons found in the soil samples was very high (approx $26 \quad 000 \quad \mathrm{mg} \quad \mathrm{TPH} \quad / \mathrm{kg}$ soil).The levels of hydrocarbons found in other contaminated site studies are similar and such levels have been subject to bioremediation. Hence, the soil in this study is expected to be amenable to bioremediation not withstanding the nutrient limitations.

\subsubsection{Bioremediation of Sandy Soils}

Bioremediation of sandy soils has received rather less attention than other soil types and there are a number of issues (in addition to nutrient limitation) that may affect microbial transformation of hydrocarbon pollutants. Sandy soils are known to reduce the transportation of phosphate and make it unavailable for biological activity [21]. Ghazali et al. [13] discussed how limited microbial growth and subsequent pollutant transformation in a fine sand was due to a lack of oxygen. The soil became waterlogged as a result of the addition of liquid. One possible reason is that the pores between sand particles are small, thus they allow less of a path for water and gas flow. Another study by Rowland et al. [41] investigated bioremediation of oily beach sand dunes on the British coast, demonstrating that when the sand became saturated with water the breakdown process appeared to stop. Thus during any bioremediation process of sandy soil it is important to ensure that the sand does not become saturated and any work should be carried out below the water holding capacity of the soil.

\subsection{Bacterial Isolation and Identification}

One particular issue with bioremediation of sandy soils may be an insufficient number of microbes and presence of microbes capable of transforming pollutants. This study was able to easily isolate bacteria from contaminated sandy soil capable of growing on hydrocarbons as a sole source of carbon and energy and five isolates in particular, were found to grow on a variety of hydrocarbon types including hexadecane, crude oil and diesel oil. They were identified by $16 \mathrm{~S}$ rRNA sequences as Pseudomonas putida, Pseudomonas species, Beta proteobacterium, Bacillus species, and Nocardiacyriacigeorgici. Use of $16 \mathrm{~S}$ rRNA is currently considered to be the 'gold standard' for bacterial identification but despite this the technique does have limitations in delineating species due to similarity in $16 \mathrm{~S}$ rRNA sequence in some genera and lack of sequence information in available searchable databases. For example, different Bacillus species are known to have similar 16S rRNA sequences and obtaining a species name can be problematic in this genus. For example, Plaza et al. [36] discussed that 16S rRNA gene sequencing could not 
clearly assign Bacillus sp. (T-1), Bacillus sp. $\left(\mathrm{T}^{\prime}-1\right)$ isolated from petroleum-contaminated soils to any species in the genus Bacillus as both isolates showed $99 \%$ similarity to two distinct species of the genus (B. subtilis and $B$. licheniformis for $\mathrm{T}-1$ and $B$. subtilis and $B$. amyloliquefaciens for $\left.\mathrm{T}^{\prime}-1\right)$. Pseudomonas species and Bacillus species are two of the most widely studied industrial microorganisms. Isolates similar to those we obtained were used by other authors to degrade hydrocarbons. Widada et al. [51] reported that the majority of hydrocarbon degrading bacteria belong to the Pseudomonas genus and Bento et al. [6] demonstrated that Bacillus species are one of the most widely studied hydrocarbon degrading bacteria. Plaza et al. [36] also discussed the ability of hydrocarbon degrader bacteria such as Pesudomonas sp., Actinobacter sp., Bacillus sp., Rhodococcus sp., and Arthobacter sp. in terms of biodegradation and biosurfactant production. In a Kuwaiti desert soil, researchers found that the predominant indigenous oil-utilizing bacteria belong to Micrococcus, Pseudomonas, Bacillus, Arthrobacter, and the group of nocardioforms, particularly the genus Rhodococcus [37]. This previous work shows that the isolates found in this study belong to known hydrocarbon transforming bacterial genera. The five isolates were then examined further for their ability to emulsify hydrocarbons and transform different oil types.

\subsection{Emulsification Activity of Bacterial Isolates}

Biosurfactants reduce surface and interfacial tensions in both aqueous solution and hydrocarbon mixtures, making them potential agents for bioremediation as in [4]. In this study, emulsification activity was used as an indicator to measure the production of biosurfactant as this method has been used in several previous studies [11,48]. Measuring the emulsifying activity of the culture broth during different stages of growth showed that activity was highest at the end of the exponential growth phase and stationary phase. Nayak et al. [29] found that in the initial $48 \mathrm{~h}$ the production of rhamnolipid was low, but that after $120 \mathrm{~h}$ levels increased and reached $280 \mathrm{mg}^{-1}$, clearly showing that to the production of biosurfactant is growth associated. Both Pseudomonas species studied here were shown to have high emulsification activity (up to $86 \%$ and $61 \%$ ), Bacillus species had $66 \%$ activity, while Nocardiacyria cigeorgici showed 53\% emulsification activity. The unidentified Beta proteobacterium isolate had only $32 \%$ activity demonstrating a wide variety of potential biosurfactant production between the isolates. Banat et al. [5] revealed that B. subtilis and B. pumilus are the only two Bacillus species that have been identified and reported as biosurfactant producer. In our study, the Bacillus species increased emulsification to $66 \%$ and therefore likely produced biosurfactant. Plaza et al. [36] stated that many microorganisms which biodegrade crude and refined oils produce surface active compounds (biosurfactants) and so the production of biosurfactants by the isolates is to be expected. Estimation of the emulsification index $\left(\mathrm{E}_{24}\right)$ has been considered one of the essential approaches for screening potential biosurfactant-producing microorganisms. Most published $\mathrm{E}_{24}$ values in the literature have been reported to be around $65 \%$ [7]. However, we obtained $86 \% \mathrm{E}_{24}$ values with Pseudomonas putida species, thus another promising microbial candidate for biosurfactant production has been identified in this research. High levels of biosurfactant production have also been found in previous work e.g. a Bacillus subtilis strain displayed E24 values close to $90 \%$ [5]. Overall, the results demonstrate that the bacteria isolated in this study have a high emulsification activity (despite the fact that emulsification activity was not optimised in this study) and these bacteria could be potentially used as inoculants to enhance bioremediation of oil contamination. All five isolates were used for further study to examine their ability to grow on various types and levels of pollutants.

\subsection{Effect of Carbon Source (Pollutant) Concentration and Temperature on Bacterial Growth}

Many studies have discussed how Pseudomonas and Bacillus species can tolerate high concentrations of hydrocarbons and have a high degradation capability. It has been suggested that Bacillus species are more tolerant to high levels of hydrocarbons in soil as Bacillus species forms endospores which are stress resistant [13,44]. Numerous genera of hydrocarbon degraders bacteria tolerate high concentrations of the hydrocarbons and have a high degradation capability. Most of them belong to Pseudomonas, Sphingomonas, Aeromonas, Alcaligenes, Acinetobacter, Arthobacter, Brevibacterium, Xanthomonas, Mycobacterium, Rhodococcus and Bacillus [36].

The Pseudomonas putida used in this work had the highest growth rates of all isolates with the $1.0 \%$ (vol) concentration of crude oil used.

All the isolated petroleum hydrocarbon degraders showed favorable growth on hydrocarbons at a temperature of $30^{\circ} \mathrm{C}$. This is supported by previous work showing that the optimum temperature for enhancing diesel degradation was $30^{\circ} \mathrm{C}$ [43]. Bossert el al. [8] suggest that the volatility and toxicity of oil increases at higher temperatures, therefore the slower growth of isolates observed in this work could be explained by an increase in temperature related toxicity. In addition, diesel oil was found to be toxic to microorganisms due to the solvent effect of diesel which destroy bacterial cell membranes, the growth of DRY11bacterial strain started to decline when the concentration of diesel was above $4 \%$ (v/v) [43]. The two isolates (P. putida and Bacillus species) that showed the highest growth rates on the hydrocarbon sources were then examined for their ability to transform hydrocarbons (diesel and crude oil) using gas chromatography analysis.

\subsection{Effect of Pseudomonas and Bacillus Species on Diesel and Crude Oil Transformation}

The total residual total petroleum hydrocarbon analysis of diesel oil showed that $P$. putida had higher transformation abilities than the Bacillus isolate under the experimental conditions used. The more detailed gas chromatographic analysis of diesel oil treated with $P$. 
putida species, in particular, showed a decrease in heavy hydrocarbon fractions as opposed to the Bacillus sp. which did not transform the higher molecular weight compounds. Most of the light parts of the intermediate weight fractions initially present in the extracted oil were degraded by both species.

The results indicate a clear difference in biodegradation potential between the 2 isolates and the ability of the $P$. putida species to remove the higher molecular oil components is of interest as these components are typically harder to transform and persist in soil bioremediation. For example, Gogoi et al. [14] demonstrated that contaminated soils are more dominated by alkane degrading microorganisms than aromatic and polyaromatic hydrocarbon degraders. The higher molecular weight hydrocarbons are more resistant to microbial degradation, and may accumulate in soil.

The levels of oil removal in this study are similar to others reported previously. For example, other studies reached high transformation, whether by increasing the temperature or expanding the incubation time. Ghazalai et al. [13] studied two strains of B. stearothermophilus and achieved 80-89\% degradation of crude oil (5 g/l) within 5 days at $60^{\circ} \mathrm{C}$. In other work, hydrocarbon-degrading bacteria were identified as Pseudomonas aeruginosa AP02. This strain showed ability to utilize a range of hydrocarbons on C5-C19 n-alkanes and polycyclic aromatic hydrocarbons as sole carbon source. The isolate degraded $99 \%$ of crude oil $1 \%(\mathrm{v} / \mathrm{v})$ and diesel oil $2 \%(\mathrm{v} / \mathrm{v})$ when added to a basal mineral medium and reached optimum growth within 7 days of incubation [34].

\subsection{Effect of Diesel Oil and Crude Oil on Growth of Pseudomonas putida and Bacillus}

In the current experiment, Pseudomonas putida was found to grow better on diesel oil compared to crude oil, and counts increased from $3.2 \times 10^{9} \mathrm{CFU} /(\mathrm{ml})$ to a maximum count of $1.0 \times 10^{10} \mathrm{CFU} /(\mathrm{ml})$ over the $21 \mathrm{~d}$ incubation. Similar increases in numbers have been observed previously [50]. In the current experiment counts of Bacillus species increased was high when crude oil used as carbon source.

The results from this work suggest that both species (Pseudomonas putida and Bacillus species) have the ability to remove hydrocarbons of different carbon chain lengths.

\section{Summary \& Conclusions}

The soil samples from the refinery were found to have low nutrient levels, have a sandy texture and to be highly contaminated with petroleum hydrocarbons. Hydrocarbon utilizing microorganisms were isolated and identified from contaminated soil samples. After initial screening of eleven isolates capable of growth on hexadecane the five most promising hydrocarbon-utilizing bacteria were isolated and tested for emulsification activity. They were identified by the $16 \mathrm{~S}$ rRNA gene as Pseudomonas putida species, Pseudomonas species, Beta proteobacterium, Nocardia cyriacigeorgici, and Bacillus species. Emulsifying capacity was evaluated using the E24 emulsification index. The isolated species exhibited high emulsification activity. Among the five species tested, Pseudomonas putida showed superior performance in terms of growth on hydrocarbons, emulsifying activity and ability to transform hydrocarbons in pure culture.

Interestingly, the gas chromatographic analysis of crude oil treated with $P$. putida showed a decrease in heavy hydrocarbon fractions demonstrating a clear potential for this microbe to be used as a soil inoculant in bioremediation. As the Bacillus isolate also grew well on crude oil and also appeared to transform high molecular weight $\mathrm{HCs}$ this organism would be a potential useful inoculant for bioremediation purposes and the two could be used in a multiple inoculation approach.

\section{References}

[1] Al-Asadi, M.K.K, Levels of oil residues in some coastal lagoons, East of Libya. Mesopot. J. Mar. Sci, 27 (1). 67-77. 2012.

[2] Althalb, H. Potential use of nutrients and biodiesel to bioremediate diesel contaminated sub-soil. Degree of Master of Science. University of Newcastle, United Kingdom, 2007.

[3] Anon, The analysis of agricultural material- ministry of agriculture fisheries and food. Reference Book 427. Stationary office. London, 1986.

[4] Banat, I.M, Biosurfactants production and use in microbial enhanced oil recovery and Pollution remediation: a review. Bioresource Technology, 51. 1-12. 1995a.

[5] Banat, I.M, Makkar, R.S, and Cameotra, S.S, Potential commercia applications of microbial surfactants. Applied Microbiology and Biotechnology, 53. 495-508. 2000a.

[6] Bento, F.M, Camargo F.A.O, Okeke BC and Jr WTF, Comparative bioremediation of soils contaminated with diesel oil by natural attenuation, biostimulation and bioaugmentation. Bioresource Technology, 96. 1049-1055. 2005a.

[7] Bento F.M, Camargo F.A.O, Okeke BC and Jr WTF, Diversity of Biosurfactant producing microorganisms isolated from soils contaminated with diesel oil. Microbiological Research, 160. 249-255. 2005b.

[8] Bossert, I., and Bartha, R., The fate of petroleum in soil ecosystem In Petroleum Microbiology, Atlas Macmillan Publishers, New York, 1984, 435-473.

[9] Boopathy, R., Factors limiting bioremediation technologies, Bioresource Technology, 74. 63-67. 2000.

[10] Bundy, G.J., Paton, G.I., and Campbell, C.D., Combind microbial community level and single species biosensor responses to monitor recovery of oil polluted soil, Soil Biology and Biochemistry, 36. 1149-1159. February. 2004.

[11] Cooper, D.G., and Goldenberg, Biosurfactants and enhanced oil recovery, in Microbial Enhanced Oil Recovery, Afton, Ok, Doe Conf-85051, 40. 112-114. 1982.

[12] Farnum, R. and Harkness, M., Laboratory Evaluation of the Biodegradation of TCE at the WWTP Area. GE Global Research Publishers, 2003.

[13] Ghazali, F., Mohamad, Rahman, R.N.Z., Salleh, A.B. and Basri, M. Biodegradation of hydrocarbons in soil by microbial consortium, International Biodeterioration Biodegradation, 54. 61-67. 2004.

[14] Gogoi, B.K., Dutta, N.N., Goswarni, P. and Mohan, T.R.K., A case study of bioremediation of petroleum-hydrocarbon contaminated soil at a crude oil spill site, Advances in Environmental Research,7. 767-782. 2003.

[15] Howage, H.M., Khalaf, M.K. and Khattali, A.O., Preliminary study on the oil pollution in the Gulf of Sirte. Journal of Basic and applied sciences, 8. 11-22. 2000

[16] Huang, X.D., EL-Alawi, Y., Gurska, J., Glick, B.R. and Greenberg, B.M., Amulti-process Phytoremediation system for persistent total petroleum hydrocarbons (TPH) from soil. Journal microchemical, 81. 139-147. 2005.

[17] Jùrgensen, K.S., Puustinen, J. Suortti, A.M., Bioremediation of petroleum hydrocarbon contaminated soil by composting in biopiles. Environmental Pollution, 107. 245-254. 2000 
[18] Keeney, D.R. and Bremner, J.M., Determination and isotope-ratio analysis of different forms of nitrogen in soils. 4. Exchangeable ammonium, nitrate, and nitrite by direct distillation methods. Soil Science Society of America Proceedings, 30. 583-58. 1966.

[19] Kumar, A., Bisht, B.S., Joshi, V.D., and Dhewa, T., Review on Bioremediation of Polluted Environment: A Management Tool, International Journal of Environmental Sciences, 1 (6). 1079-1093. 2011.

[20] Lai, C.C., Huang, Y.C., Wei, Y.H., Chang, J.S., Biosurfactantenhanced removal of total petroleum hydrocarbons from contaminated soil, Journal of Hazardous Materials, 167. 609-614. 2009.

[21] Liebeg, E.W. and Cutright, T., The investigation of enhanced bioremediation through the addition of macro and micro nutrients in a PAH contaminated soil, International Biodeterioration and Biodegradation, 55-64. 1999.

[22] Liu, B., Banks, M., Schwab, P., Effects of soil water content on biodegradation of phenanthrene in a mixture of organic contaminants, Soil Sediment Contam, 10. 633-658. 2001.

[23] Lucas, J.A., Wibberley, L.J., Kennedy, E.M., and Dlugogorski, B Z., Hydrocarbon contaminated soil and the development of an innovative thermal process, ANZ Geo. Environment, 28-30. 2001.

[24] Lynch, J.M. and Moffat, A.J., Bioremediation-prospects for the future application of innovative applied biological research, Annals of Applied Biology, 146. 217-221. 2005.

[25] Madigan, M.T., Martinko, J.M. and Parker, J., Biology of Microorganisms, 9th edn. Prentic Hall, Inc. New York. 2000.

[26] Maila, M.P., Microbial ecology and bio-monitoring of total petroleum contaminated soil environment. Thesis for $P h D$. university of Pretoria, South African (2005).

[27] Mcmillen, S., Bioremediation Overview - ChevronTexaco. Presentation at DOE/PERF Bioremediation Works. 1994.

[28] Muyzer, G., Waal, E.C.D., Uitterlinden, A.G.,. Profiling of complex Microbial populations by denaturing Gradient gel electrophoresis analysis of polymerase chain reaction- amplified genes coding for $16 \mathrm{~S}$ rRNA. Applied and Environmental Microbiology. 59 (3). 695-700. Mar. 1993.

[29] Nayak, A.S., Vijaykumar, M.H., Karegoudar, T.B., Characterization of biosurfactant produced by Pseudoxanthomonas sp. PNK-04 and its application in bioremediation, International Biodeterioration \& Biodegradation, 63. 73-79. 2009.

[30] Nikolopoulou, M. and Kalogerakis, N., Enhanced bioremediation of crude oil utilizing lipophilic fertilizers combined with biosurfactants and molasses, Marine Pollution Bulletin, 56. 1855-1861. 2008.

[31] Odokuma, L.O. and Akponah, E., Effect of nutrient supplementation onbiodegradation and metal uptake by three bacteria in crude oil impacted fresh and brackish waters of the Niger Delta, Cell and Animal Biology, 4. 001-018. 2010.

[32] Okoh, A.I., Biodegradation alternative in the cleanup of petroleum hydrocarbon pollutants, Biotechnology and Molecular Biology, 1. 38-50. 2006.

[33] Olsen, S.R., Cole, V.C., Watanabe, F.S. and Dean, L.A., Estimation of available phosphorus in soils by extraction with sodium bicarbonate, Departmentof Agriculture Circular, U.S. 1954.

[34] Perfumo, A., Banat, I.M., Canganella, F. and Marchant, R., Rhamnolipid production by a novel thermophilic hydrocarbondegrading Pseudomonas aeruginosa AP02-1, Applied Microbiology and Biotechnology, 72. 132-138. 2006.

[35] Peltola, R., Bioavailability aspects of hydrophobic contaminant degradation in soils, Thesis for phD. University of Helsink. 2008.

[36] Plaza, G.A., Lukasik, K., Wypych, J., Nalecz-Jawecki, G., Berry, C. and Brigmon, R.., Biodegradation of Crude Oil and Distillation Products by Biosurfactant-Producing Bacteria, Polish Journal of Environmental Studies, 17. 87-94. 2008a.
[37] Radwan, S.S., Microbiology of Oil- Contaminated Desert Soils and Coastal Areas in the Arabian Gulf Region, Microbiology of Extreme Soils. Soil Biology ed. by Dion and Nautiyal CS, Berlin, 13. 275-298. 2008.

[38] Rahman, K.S., Banat, I.M., Thahira, J., Thayumanavan, T. and Lakshmanaperumalsamy, P., Bioremediation of gasoline contaminated soil by a bacterial consortium amended with poultry litter, coir pith and rhamnolipid biosurfactant, BioresourTechnol, 81. 25-32. 2002.

[39] Raghavan, P.U.M. and Vivekanandan, M., Bioremediation of oil-spilled sites throughseeding of naturally adapted Pseudomonas putida, International Biodeterioration and Biodegradation, 44. 29-32. 1999.

[40] Reddy, M.S., Basha, S., Joshi, H.V., Ramachandraiah, G., Seasonal distribution and contamination level of total PAHs and heavy metals in coastal waters of the Alang-Sosiya ship scrapping yard, Gulf of Cambay, India, Chemosphere, 61. 1587-1593. 2005.

[41] Rowland, A.P., Lindley, D.K., Hall, G.H., Rossal, 1.M.J., Wilson, D.R., Benham, D.G., Harrison, A.F. and Daniels, R.E., Effects of beach sand properties, temperature and rainfall on the degradation rates of oil in buried oil/beach sand mixtures, Environmental Pollution, 109. 109-118. 2000.

[42] Schneiker, S., Santos, V.M., Bartels, D., Bekel, T., Brecht, M., Buhrmester, J., Chernikova, T.N., Denaro, R., Ferrer, M., Gertler, C., Goesmann, A., Golyshina, O.V., Kaminski, F., Khachane, A.N., Lang, S., Linke, B., McHardy, A.C., Meyer, F., Nechitaylo, T., Pühler, A., Regenhardt, D., Rupp, O., Sabirova, J.S., Selbitschka, W., Yakimov, M.M., Timmis, K.N., Vorhölter, F.J., Weidner, S., Kaiser, O., Golyshin, P.N., Genome sequence of the ubiquitous hydrocarbon degradingmarine bacterium Alcanivoraxborkumensis, 24. 997-1004. 2006

[43] Shukor, M.Y., Dahalan, F.A., Jusoh, A.Z., Muse, R., Shamaan, N.A. and Syed, M.A., Characterization of a diesel-degrading strain isolated from a hydrocarbon-contaminated site, Journal of Environmental Biology, 30. 145-150. 2009.

[44] Singh, C., Lin, J., Isolation and characterization of diesel oil degrading indigenous microrganisms in Kwazulu-Natal, South Africa, African Journal of Biotechnology. 7. 1927-1932. 2008.

[45] Sokhn, J., De Leij, F.A.A.M., Hart, T. D and Lynch, J.M., Effect of copper on the degradation of phenanthrene by soil microorganisms, Letters in Applied Microbiology, 33. 164-168. 2001.

[46] Sulivan, K.M. and Skladany, G.J., Decay theory biological treatment for low level organic contaminated ground-water and industrial waste. In superfund 87: proc, $8^{\text {th }}$ National conference, silver spring, MD 1987.

[47] Supaphol, S., Panichsakpatana, S., Trakulnaleamsai, S., Tungkananuruk, N., Roughjanajirapa, P. and O'Donell, A.G., The selection of mixed microbial inocula in environmental biotechnology: example using petroleum contaminated tropical soils, Journal of Microbiological Methods, 65. 432-441. 2006.

[48] Thavasi, R., Jayalakshmi, S. and Banat, I.M., Biosurfactants from marine bacterial isolates, Applied microbiology and microbial biotechnology, 1367-1373. 2010.

[49] Ueno, A., Ito, Y., Yamamoto, Y., Yumoto, I. and Okuyama, H., Bacterial community changes in diesel-oil-contaminated soil microcosms biostimulated with LURIA BERTANI medium orbioaugmented with a petroleum-degrading bacterium, Pseudomonas eruginosa strain WatG, Basic Microbiol, 46. 310-317. 2006.

[50] Ward, O., Singh, A. and Hamme, J.V., Accelerated biodegradation of petroleum hydrocarbon waste, Journal of Industrial Microbiology and Biotechnology, 30. 260-270. 2003.

[51] Widada, J., Nojiri, H., Kasuga, K., Yoshida, T., Habe, H. and Omori, T., Moleculardetection and diversity of polycyclic aromatic hydrocarbon-degrading bacteria isolated from geographically diverse sites, Applied Microbiology and Biotechnolology, 58. 202-209. 2002. 